\title{
Transgovernmentalism Meets Security: Police Liaison Officers, Terrorism, and Statist Transnationalism
}

\author{
ERSEL AYDINLI* and HASAN YÖN*
}

\begin{abstract}
Studies of transgovernmental activities have enhanced our understanding of changing global politics, but their claims have not been fully investigated with respect to the security realm. Therefore, this article first acknowledges a gap between the practices and capacities of nonstate entities creating transnational threats and those of state-based agents of response. States' ability to respond to these threats has been questioned. Is this skepticism warranted or have states begun adapting and developing new responses to address nonstate security challenges? This article looks at transgovernmental responses to transnational terrorism and identifies an unconventional group of substate pioneers, police liaison officers (PLO), making moves into the transnational realm. Data collected through interviews with international PLOs reveal these activities to be characterized by increasing informality, depoliticization, and demonopolization of global security cooperation. This cooperation nevertheless maintains its strong ties with state legitimacy and capacity, and is therefore conceptualized here as statist transnationalism.
\end{abstract}

\section{Introduction}

The nature of global security threats has changed, from the primacy of state-based challenges during the Cold War era to the rise of transnational issues and nonstate actor challengers of recent years. These transnational threats have been linked to such diverse sources as environmental degradation, disease, and migration, to crime and terrorism, ${ }^{1}$ and their growing significance has spawned various efforts to describe and reconceptualize security in world politics (Baldwin 1997; Buzan, Waever, and deWilde 1997; Dupont 2001; Mandel 1999). It can be generally agreed upon, though, that we have entered into an era in which newly empowered forces-from individuals to associations or organizations of various levels of formality-have been released, ${ }^{2}$ not only in the realms of economic, social, or political issues but also in that of security. Widespread acceptance of changes in the nature of security threats naturally raises questions about what these changes might mean for the traditional responder to

*Bilkent University

Governance: An International Journal of Policy, Administration, and Institutions, Vol. 24, No. 1, January 2011 (pp. 55-84).

(c) 2010 Wiley Periodicals, Inc., 350 Main St., Malden, MA 02148, USA, and 9600 Garsington Road, Oxford, OX4 2DQ, UK. ISSN 0952-1895 
global threats, the state. Are states also changing? Are they adapting their response practices to meet these new threats, or are they failing to do so and thus becoming increasingly irrelevant?

To explore this question it is necessary to consider a nonstate, transnational security threat that has managed to generate broad state response, and examine the range and nature of that response. An appropriate example of such a threat is terrorism. Since the attacks of 9/11 in particular, "new" characteristics of terrorism have been pointed out, all of which emphasize the increasingly nonstatist, transnational nature of many terrorist groups and incidents. These include a shift in "new" terrorist groups' organizational structure from hierarchical to networked and decentralized (Arquilla, Ronfeldt, and Zanini 1999), these groups' increasing use of information technology both for communication purposes as well as for attacks (Coll and Glasser 2005; Denning 2002; Hinde 2001; Stohl 2006), and a broadening - globalizing - of strategies to achieve goals that may or may not remain relatively local. Also noted has been "new" terrorism's increasingly religious nature (Juergensmeyer 2003; Sedgwick 2004) (transnational in its being not directly associated with a particular nation) and finally, a reduced, if not eliminated, reliance on state sponsorship for survival (Kittner 2007; Newman 2007; Takeyh and Gvosdev 2002).

As for the response, unlike other nonstate transnational security challenges like environmental degradation, refugee crises, and human or small arms trafficking, this "new," transnational terrorism, as generally associated with al Qaeda and radical Jihadism, has indeed provoked a major international response. It has managed to garner greater state interest than other nonstate security challenges first because its targets have included the world hegemon and other influential Western countries, and also because of the inevitable response cycle that terrorist attacks demand-in order to appease public fear and outrage, governments feel obliged to respond without delay and generally without restraint. By looking therefore at states' countering practices toward transnational terrorism, it may be possible to find evidence of whether states are indeed adapting in their responses to new transnational security threats.

In this article we argue that states are adapting and that evidence for this can be found in the increasingly accepted and institutionalized use of liaisons, particularly police liaisons, in response to transnational threats. Although liasionship in itself is not a new phenomenon, the number of liaisons has been growing in recent years and there is evidence to suggest that the nature of liaison activity is changing, from an ad hoc response to various threats to a regular, established practice of state-supported transnational security enforcement. This last point is of particular significance: Liaison activity is occurring within the security realm, a realm that has traditionally remained within the tight and exclusive control of the state. Changes and signs of adaptation in this realm may therefore be construed as signs of adaptation on the part of states, as an attempt to support innovative strategies for the governance of new transnational challenges. 
The article first provides an overview of perspectives taken on the question of whether states are in decline, considering views from the international relations scholarship on globalization and the state as well as from the literature on governance. We then look at transgovernmental efforts being made by substate actors to combat transnational security challenges, and in particular, transnational terrorism. The following section focuses on what emerges as a particularly vibrant area of statebased response activity_police liaison officers (PLOs) — and explores the extent and types of developments in the appointments and practices of PLOs as possible evidence of states' adaptation capacity with respect to the transnationalization of (in)security.

\section{States and Governance in Transition}

A variety of scholars in recent decades have considered-either directly or indirectly-the question of the state's ability to adapt to changes in patterns of global politics and therefore remain a relevant actor. These scholars have come from various theoretical and paradigmatic backgrounds and have not only approached the question in very different manners but also come to varying conclusions. While there seems to be little doubt among all of them that the state and its governing practices are changing (Burris, Kempa, and Shearing 2008), there remains considerable disagreement about how it is changing and what the implications of that change might be for the state itself. Nevertheless, two general patterns can be traced: Some see the state and the state system as being in decline and of decreasing relevance, and some do not.

Within the broad international relations literature, among scholars exploring the question of how the state is coping in an era of transnational growth, there are those who have come to the conclusion that the state is in decline (e.g., Ferguson and Mansbach 2007; Mathews 1997; Ohmae 1995; Sassen 1996; Strange 1996) and that the state can no longer be considered the sole governing body (Fidler 2004; Ruggie 2003; Stiglitz 2002; Zurn 2004). Such a view of states' apparent incapacity to adapt and thus maintain their dominant grip on power would lead to the assumption that in security issues, with new actors and challenges rising on one side but traditional actors and response approaches still prevalent on the other, a gap must emerge between the practices and capacities of the nonstate entities creating transnational challenges and threats, and the practices and capacities of the state-based agents of response. A failure or inability to adapt would mean that the state-based responders are not taking advantage of the very changes that are allowing the threats to evolve. It would indicate that while global ideational, material, or scientific transformations in principle provide everyone opportunities to flourish and develop, it is the transnational nonstate actors who seem to have an inherent advantage over the more bureaucratic actors and patterns of the international realm. While such a gap between threat and response would 
not necessarily mean that the state no longer has any significance or relevance in countering security threats, it would contribute to an image of the state as a "dinosaur at the end of the Cretaceous period, powerful but cumbersome, not yet superseded, but no longer the unchallenged masters of their environment" (Singer 2001/02, 213).

Another large body of scholarship dealing with changes in the state is that on governance, in which we also find works-this time a clear majority - attesting to the decline of the state. Again there is the claim that the state is in decline because the forces of globalization (Teubner 2004), as well as considerable work arguing that the new era of governance can be better described using a "network" metaphor that captures the idea of power and authority shifting away from monolithic states toward an increasing distribution among nonstate and hybrid bodies (Bevir and Rhodes 2003a; Bevir, Rhodes, and Weller 2003; Burris, Drahos, and Shearing 2005; Castells 2000; Scott 2000; Slaughter 2001). These ideas overlap broadly with the transgovernmental perspective in IR, which also takes as a starting point the idea that the state can no longer be considered as a unitary whole but must be treated as a disaggregated entity. The transgovernmental perspective is based on Keohane and Nye's (1974) longstanding distinction of activity occurring between "sub-units of governments on those occasions when they act relatively autonomously from higher authority in international politics," and highlights the process of "substate" authorities building up transgovernmental capacities on their own, in the sense of coordinating and building up networks with other substate entities.

In terms of exactly who these various agencies gaining power at the expense of the state are, considerable scholarship has been devoted to discussion of corporate power at the local, national, and inter/ supranational levels (Bevir and Rhodes 2003a, 2003b; Bevir, Rhodes, and Weller 2003; Freeman 2000; Shearing 2005), with certain strong arguments being made that private corporations actually are the government in some communities (Sinden 2007). In terms of the ways in which this power shift has been occurring, the global business regulation literature in particular has explored how legal and cultural conditions have enabled corporations to take means of governance authority away from public authorities (Braithwaite and Drahos 2000; Drahos and Braithwaite 2003; Levi-Faur 2005; Moran 2002; Scott 2002). Additionally, works on autonomous regulatory authorities have explored the ways in which public authorities themselves have delegated power away from bureaucrats to professionals and technocrats, leading to what has been dubbed "indirect representative democracies" (Jordana and Levi-Faur 2005).

A growing body of both IR and governance scholarship makes the point that the state is not only no longer the only way of governance, it is also not the best way when it comes to dealing with such issues as the environment (Betsill and Bulkeley 2004; DesRues 2005; Jonas and Bridge 2003; Selin and VanDeveer 2005), human rights (Cardenas 2003a, 2003b) international 
development (Diawara 2000), health (Cohen 2006; Kickbusch 2005, 2006), or even legal matters (Eberlein and Newman 2008; Newman 2008; Raustiala 2002). Often this work explores the growing authority of nongovernmental organizations (NGOs) (Braithwaite 2006; Collingwood and Logister 2005; Haque 2004; Spiro 2007). In these cases, power for the NGOs is generally attributed to these organizations' influential role in keeping particular issues on the global agenda. The argument is made that for some issues, for example human rights, medicine, trade, and agriculture, the role of NGOs and NGO networks is crucial (Csete 2004; Sell 2004). In extreme cases, NGOs such as the Bill and Melinda Gates Foundation are seen as having taken virtual control of the agenda on a particular issue (Cohen 2006).

With respect to the question of security-related issues, the general arguments of a shifting of power away from the state have again been made, again most often with an emphasis on a move to agencies outside of the state. There are frequent references to the privatizing of security forces in general (deNevers 2009a, 2009b; Krahmann 2010; Singer 2004a), the privatizing of policing ${ }^{3}$ in particular (Juska 2009; Kempa, Stenning, and Wood 2004; Wakefield 2003), and to the regulatory options for such private security forces (Avant 2005; Chesterman and Lehnardt 2007; Holmqvist 2005; Percy 2006; Schreier and Caparini 2005; Singer 2004b; Spear 2006). The overall growth of security-related networks has been also pointed out (Adamson 2005), and the need for exploring networks in transnational security issues has been expressed both for methodological purposes (Krahmann 2005) and as a means for countering terrorism (Gerspacher and Dupont 2007). Loss of state power in security issues has also been viewed from the perspective of looking at the threatening nonstate actors themselves and exploring how their use of violent power raises risk factors, and thus "controls" governance through force or threat of force (Beck 1999; Garland 2000; Raab and Milward 2003).

Despite such arguments to the contrary, many scholars maintain that predictions of the state's demise have been overestimated (Krasner 1999; Lagon 2003; Paul and Hall 1999; Paul, Ikenberry, and Hall 2003; Weiss 1998). After $9 / 11$ in particular, the point has been made that the new threats or the severity of them have brought about a return of the state (Fukuyama 2004; Hall 2002; Telhami 2006). With failed or failing states viewed by many as breeding grounds for various transnational threats but most potently, terrorism (Dorff 2005; Krasner and Pascual 2005; Piazza 2008; Rotbert 2002), the argument goes that security is to be found in a renewed promotion of states and the protecting of state sovereignty. It is perhaps not a coincidence that particularly with respect to security issues, it is more difficult to find arguments of the state's diminishing power (Crawford 2006; Loader and Walker 2006; Zedner 2003); rather, the tendency is either toward seeking ways of strengthening state response (Loader and Walker 2007) or toward arguing that (particularly post-9/11) state power has gained excessively and must be kept under control (O'Reilly and Ellison 2006). Even among those who see a branching out of 
state power into network structures, the argument has been made that states may actually gain strength - because of their role of still being the coordinating transmitters of decisions to various agencies (Shearing 2005). Similarly, the extensive work done on "reinventing government" looks at ways of transforming state structures in order to increase their capacity to control diffused power from a centralized position, for example, in the form of the regulatory state (Braithwaite and Drahos 2000; Levi-Faur 2005; Moran 2002)

While both perspectives on the state's position in global politics make reasonable arguments, when it comes to security, both also have shortcomings, largely stemming from the failure of either side to clearly base their position on substantive empirical evidence of states' actual response practices. This is first true for those who say that rising threats and fearfulness lead people to turn to states for help, and therefore the importance of the state remains strong. Events of the last decade in Iraq or Afghanistan may have brought back a sense of appreciation for the state and given a boost to the idea that a lack of state control and protection leads to greater insecurity; however, such a conclusion cannot be automatically construed as a sign that states are indeed successfully adapting to meet the new kinds of challenges and provide the necessary security. In other words, resumed desire for an all-protecting state does not mean that the state can effectively fill this role. Turning to those who have suggested that the role of the state is shrinking, the assumption with respect to adaptability is presumably that the state either cannot or does not want to adapt, which is why it is gradually being replaced by other actors. Naturally, the tendency has been, therefore, to concentrate on the new-and thus more interesting-responding actors, specifically, nonstate responders to security. There are some who have looked directly at the state, but these have emphasized the legal dilemmas that emerge when states try to adapt to dealing with nonstate transnational threats (Behr 2008; Messina 2008; Ramasamy 2006). There remains scarce coverage of actual security-related transgovernmental activities, in the sense of those transborder activities being conducted by substate entities. The question remains, therefore, what such a transgovernmental perspective might reveal about the current state of the state with respect to security, and, specifically, to the question of whether states are adapting their response practices to meet new challenges.

\section{Transgovernmental Initiatives for Transnational Security Governance: The Case of Police Liaisons}

If initiatives for combating transnational security threats are placed on a continuum ranging from the transborder actions of official representatives of unitary nation states (international activity) to transborder actions by completely nonstate actors (transnational activity), activity occurring in between the two-or combining the two-will be considered here as 
transgovernmental practices. Although undoubtedly a part of the state realm and acting on behalf of their nation states, transgovernmental actors may in practice lean closer to the transnational.

In the security realm, transgovernmental activity between state-related actors is not easy to find evidence of-perhaps because such activity is not that common on the part of state security providers or perhaps because of the often closed nature of, for example, intelligence services. There is evidence, however, of such activity occurring among the police. Longstanding examples include cooperation among groups like the International Police Association, the International Association of Women Police, the International Association of Chiefs of Police, and the International Police Executive Symposium, as well as regional groups like the Association of Southeast Asian Nations Chiefs of National Police and the South Asian Association for Regional Cooperation, the Eastern, Western, Central and Southern Africa Police Chiefs Organizations, and in North America, the International Association of Chiefs of Police. In South America there are similar initiatives, for example, within the trading block formed by Brazil, Uruguay, Argentina, and Paraguay (MERCOSUR), member nation police forces have regular meetings to discuss police matters, and exchanges of personnel and training are common. These organizations have contributed to shared understandings among police officers around the world in different ways, from increasing social interactions among its members to organizing conferences to discuss specific police problems. They do not necessarily serve, however, the aim of improving the global countering potential against transnational terrorism because they lack the jurisdiction and muscle to enforce wide-reaching security cooperation practices.

Other long-standing examples of transgovernmental police activity include the regular meetings of the heads of police from Berlin, Bratislava, Budapest, Munich, Prague, and Vienna (Edelbacher 2001) and the close cooperation that has existed since the 1980s in the tri-national Upper Rhine Area between the police departments of Basel (Switzerland), Freiburg (Germany), and Mulhouse (France) (Mohler 2001). Substate efforts at the level of the national police include those by the Netherlands, who have established Police Partnership Programs with Hungary, Poland, and the Czech Republic, for purposes of exchanging professional knowledge and experience, and building up mutual understanding and respect (Mlicki 2001), and the well-known example of police cooperation that exists between France and England for the purpose of securing the Channel Tunnel Region.

Turning more specifically to transgovernmental police cooperation efforts to counter transnational terrorism, interesting developments have taken place in the past decade. The Metropolitan Police of London and its Counter Terrorism Command, once a purely local department, has taken responsibility for counterterrorism investigations not only in London but throughout the United Kingdom and abroad. It serves as the "single point 
of contact for international partners in counter-terrorism" with an ability to "investigate overseas attacks against British interests" (Metropolitan Police of London nd). Other recent innovations can be seen in New York City, where the local police department (NYPD) has begun sending its own police officers to work in a variety of countries, including England, Jordan, Singapore, Israel, Canada, France, and the Dominican Republic. The NYPD has also employed a Turkish-origin nonofficer to serve as a liaison between the NYPD and the Muslim community at large. He is officially entitled as a community coordinator but carries a police ID and works at police headquarters directly under the police commissioner. He is involved with the establishing of NYPD liaison offices around the world and describes his role in working with them in this way:

Officers have my name in their phone books. When they need to know anything special about Islam or Islamic culture, they just call me and ask. I inform them about what they would like to learn ... I take part during the international visits of police forces from Muslim countries to NYPD and Raymond Kelly. This situation surprises visiting delegations because although I am originally a civilian I have a role in official circles. (interviewed in New York by authors, March $3,2007)$

This civilian-officer stressed his close working relationship with the police commissioner, which may, interestingly, point to a potential shortcoming of this type of local initiatives: Although they constitute positive moves, they may be completely ad hoc and reliant on a single individual-in this case New York Police Commissioner Raymond Kelly—and thus run the risk of being discontinued or sidelined when a new person takes over.

The NYPD experience is a small-scale example of what is perhaps the most widely known and also the most rapidly expanding and diversifying practice of transgovernmental activity for combating transnational security challenges: police liaisonship. Although not a new practice-liaisons have been used since the times of an earlier transnational security threat (the Anarchists; see Aydinli 2008) and became common practice in the peaking era of another transnational threat (international drug trafficking) - their increased use in recent years and the understanding of the adaptability of this form of response to counter transnational threats seems to guarantee that they will only gain in importance in the future. The idea of police liaisons refers most commonly to the practice of either government to international organization appointments (national police organizations sending police officers to serve in an international structure like Europol) or government to government (appointing police liaisons in a bilateral manner between two states). Traditionally, bilateral liaisonships have been established between the central police structures of two countries, although in some cases, bilateral liaison officers may be used as accredited liaison officers for other regional countries (e.g., a liaison officer from one Nordic country may represent all Nordic countries in the host country). 


\section{FIGURE 1}

\section{Methods of Liaison Officer Deployment}

\begin{tabular}{|c|c|c|c|c|c|}
\hline & \multicolumn{4}{|c|}{ PLO employing entity } \\
\hline & & \multicolumn{2}{|r|}{ Bilateral annointment at } & $\begin{array}{l}\text { International } \\
\text { organization } \\
\text { (IO) }\end{array}$ & $\begin{array}{l}\text { Local } \\
\text { authorities }\end{array}$ \\
\hline \multirow{7}{*}{ 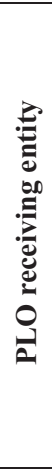 } & \multirow{4}{*}{ State } & \multirow[t]{2}{*}{$\begin{array}{l}\text { 1. Stationing in one } \\
\text { country }\end{array}$} & $\begin{array}{l}\text { Bilateral appointment at } \\
\text { general police } \\
\text { headquarters/other site }\end{array}$ & \multirow{4}{*}{$\begin{array}{l}\text { Europol LO } \\
\text { appointed to } \\
\text { USA }\end{array}$} & \multirow{4}{*}{$\begin{array}{l}\text { NYPD LOs } \\
\text { appointed } \\
\text { to other } \\
\text { countries }\end{array}$} \\
\hline & & & $\begin{array}{l}\text { Representation by other } \\
\text { LO, e.g., military attache }\end{array}$ & & \\
\hline & & \multicolumn{2}{|c|}{ 2. Accredited to other states in the same region } & & \\
\hline & & \multicolumn{2}{|c|}{ 3. Representing other states in the host country } & & \\
\hline & \multirow[b]{2}{*}{$\begin{array}{l}\text { International } \\
\text { organization } \\
\text { (IO) }\end{array}$} & \multicolumn{2}{|c|}{ 1. Membership structure (e.g., Europol) } & LOs appointed & NYPD LO \\
\hline & & \multicolumn{2}{|c|}{$\begin{array}{l}\text { 2. Appointment of nonmember countries' LOs } \\
\text { to an IO }\end{array}$} & $\begin{array}{l}\text { between } \\
\text { Interpol } \\
\text { and Europol }\end{array}$ & $\begin{array}{l}\text { appointed to } \\
\text { Interpol }\end{array}$ \\
\hline & Local authority & \multicolumn{2}{|c|}{$\begin{array}{l}\text { Jordan, Jamaica, } \\
\text { South Korean LOs in } \\
\text { New York }\end{array}$} & & $\begin{array}{l}\text { European } \\
\text { examples, } \\
\text { esp. between } \\
\text { border cities }\end{array}$ \\
\hline
\end{tabular}

In addition to the New York City example, other variations have also begun emerging in recent years (see Figure 1), such as the employing of liaison officers from nonmember states to member-based international organizations (e.g., non-EU member country liaison officers appointed to Europol), or the reverse-employing liaison officers from international organizations to nonmember states (e.g., officers from Europol posted as liaisons in Washington, DC). There is also increasing practice of liaison officers being appointed between international organizations, as is the case with liaison officer exchanges between Europol and Interpol. It has also been noted in cases where a PLO has not yet been assigned, that another existing LO (e.g., from the military) is temporarily assigned to liaise with the local police. All of these newer trends in liaison officer exchanges have taken place in the post-9/11 era and all with an overt purpose of responding to transnational terrorism.

In addition to this diversifying of PLO appointment types, there appears to be a trend for increasing numbers of PLO appointments post9/11. To get an idea about current numbers of PLOs as well as a sense of trends in PLO appointments, e-mail requests for such information were sent directly to 82 national police departments worldwide, Internet searches were made for "police cooperation agreements" and "PLOs," and examinations were done of news reports, reports from international organizations, and Web pages of police organizations. Results for numbers of PLOs as of 2009 were as follows: Approximately 54 countries were deploying PLOs to a total of 647 different sites (see Figure 2 and the Appendix for detailed information). The number of sites does not necessarily reflect the total number of actual officers, however, because more than one officer may be appointed to a single liaison office. 


\section{FIGURE 2}

\section{Distribution of Countries Based on the Number of Appointment Sites}

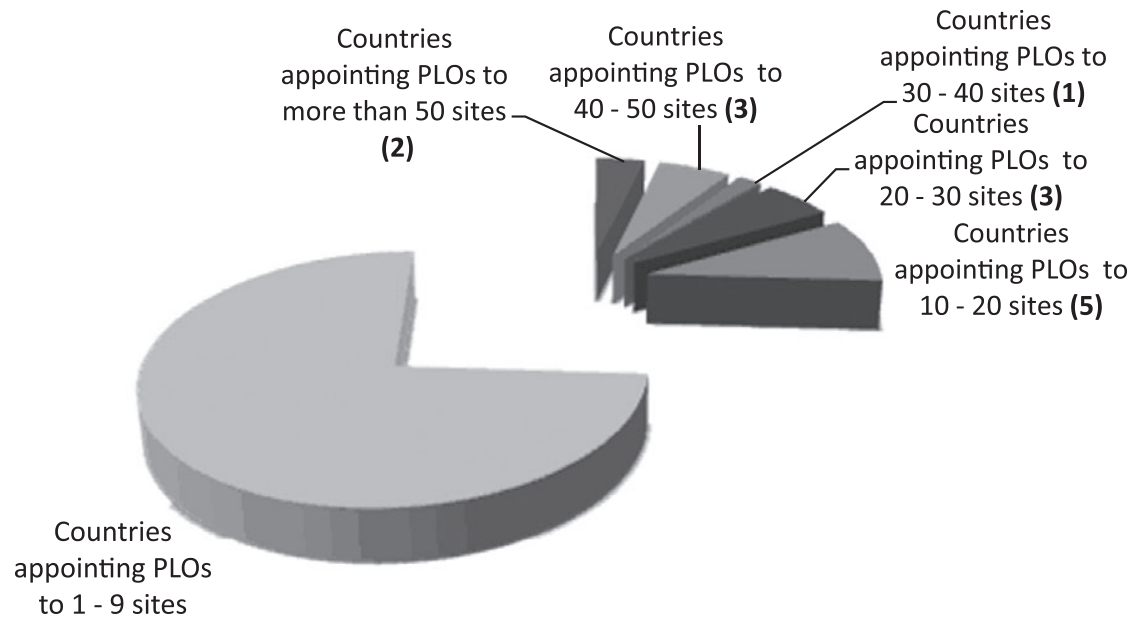

(40)

In general, these numbers are most likely underestimates of the total number of PLOs stationed around the world currently. When direct contact with national police organizations was able to be established, it tended to reveal more liaison agreements and postings than those found in the Internet search. For example, no information about Lebanese police agreements was available on the Internet, but an e-mail from Lebanese authorities showed that they have recently established bilateral police cooperation agreements with four other countries, and while the Internet search showed only four PLOs stationed in Lebanon, the e-mail response attested to a total of 15 . Similarly, the Internet search found just eight Slovak PLOs posted abroad, one foreign PLO in Slovakia, and a total of eight police agreements between Slovakia and other countries. Direct reporting by the Slovakian authorities, however, stated a total of 10 Slovak PLOs abroad, 6 foreign PLOs in Slovakia, 9 foreign PLOs with agreements to work on behalf of Slovakia, and 26 police agreements with other countries.

Most importantly perhaps, responses from various police organizations suggest that these numbers represent a dramatic rise in the popularity and overall numbers of PLO appointments since 9/11, with clearly expressed intentions to further increase the numbers of PLOs currently posted. For example, Polish authorities predict increases from current numbers of 7-10 PLOs to about 15 in the next few years, and Slovakia also reported intentions to open up two additional PLO posts in the coming year. The trend can be seen in other countries as well. The Webpage of the New Zealand Police announces that establishing new liaison posts is seen as an 
important step in increasing capability to preempt and respond to terrorist attacks, and the acting deputy commissioner of the New Zealand Police has said that international cooperation is vital; therefore, their PLO network has been spreading since 2001 (McKenzie-McLean 2006). The international network of Australian PLOs has been growing to the point that it now gives them reach into virtually every corner of the globe and has been compared in its vastness to that of the United States, with references to Australia being the "new regional policeman" (McPhedran 2004). In Asia, the ASEAN countries have several new efforts focused on improving cooperation on crimes, particularly terrorism, and the exchange of PLOs is becoming an important component of this cooperation. The fifth ASEAN meeting in 2005 focused on the establishment of PLOs in the member countries, and China has called for closer cooperation and for greater exchange of PLOs (Xinhua News Agency 2007).

Overall, the United States seems to have the lead in appointing PLOs. ${ }^{4}$ This is in part because the United States has more than one agency appointing officers, each with a different focus. These include the Drug Enforcement Agency, the FBI, the Department of Homeland Security, the State Department, and the Department of Immigration and Naturalization. The FBI alone has seen a $70 \%$ rise in the number of offices worldwide since 9/11, from 16 in 1992, to 44 in the early 1990s, to 57 after 9/11 (FBI Website nd). Former FBI director Louis Freeh testified in post-9/11 hearings that the FBI needed to "significantly increase its international role and liaison with our foreign law enforcement and security counterparts," and in reference to the 1996 Khobar bombings, stated that he could have responded better if he had "had an FBI agent in Riyadh on June 25th, 1996, when that tragedy occurred, who had the trust and the relationship that the legate [liaison officer] had three years later when he set up the office" (Freeh 2002).

The above survey of transgovernmental police efforts to combat transnational terrorism suggests that PLOs are a prime example of an adapting and vibrant area of substate response to transnational terrorism. PLOs are not only the actors of an expanding area of activity but are also agents with the potential capacity, legitimacy, and experience for pioneering innovative and transformative practices to counter transnational terrorism. The following section explores police liaisonships in greater detail in an attempt to discover whether these officers' practices tend more toward one side of an international/transnational spectrum than the other; if so, why; and what insights this might hold for understanding the adaptive and transformative capacity of the state.

\section{PLOs Going Transnational}

Bilateral appointments appear to be preferred by the PLOs primarily because they allow police officers more opportunities to take advantage of what we could call the transnational characteristics of this transgovern- 
mental activity-characteristics that allow them to act when needed, quickly, and creatively. In fact, PLOs take advantage of their transgovernmental status to draw on both sides of the response spectrum described earlier, ranging from transnational (nonstate) to international (statist) response mechanisms and practices. While maintaining the legitimacy, strength, and operational capacity that comes from being a part of the international, state system, PLOs are also establishing transnational links. The key to this transnationality seems to lie in the fact that even when their practices preserve their formally established and thus state-based nature, and even though they continue to work on behalf of their country, bilaterally appointed PLOs are likely to be functioning informally. If official cooperation takes place within bureaucratic circles, via agreements, conventions, and legal documents, a liaison officer's informal activities evolve around the time she or he spends with colleagues, sharing information and experiences. Often communication begins at the personal level:

When I meet with other cops it's easy to start talking because we all seem to have the same problems. We're all usually underpaid, and most of us have this feeling that somehow we don't get fully appreciated for the work we do. (North American PLO, interviewed March 10, 2007)

Through regular, informal interaction, they seem to establish friendships and develop trust, all of which contributes positively to the formal efforts of cooperating on security issues.

Beyond the affective benefits of this informality, many PLOs argue that there are also pragmatic ones. In the process of working on requests or cases, on-site liaison officers who encounter procedural or bureaucratic problems in sharing information can meet face-to-face and discuss ways of overcoming this difficulty. For example, formal official procedures require following institutional channels of police cooperation. These official procedures may demand that officers notify higher-level administrators for permission to exchange certain pieces of information, that they use official written forms to request information or permission, or even that they use specified formal language when requesting or sending messages. In order to set up and conduct contacts between countries, there may be requirements to copy these messages to other state-related departments, from the Interior Ministry to the Foreign Ministry or the Prime Minister's Office:

When I want to get certain information about a case, I am supposed to submit official requests in writing and these have to get OKed at several levels. The problem is when we're in the middle of an investigation it's never so simple as just one request. I need to get one answer, ask another question, get another answer, and this back and forth is nearly impossible through official requests. (Eurasian PLO, interviewed December 6, 2007)

Not only do these formalities inevitably slow down the process of information exchange and cooperation, they may also reduce individuals' willingness to share information, as they might be intimidated by the necessity of writing formal, traceable requests. On the other hand, infor- 
mal cooperation can ease the process of communication about particular cases and developments within them. By reducing some natural mistrust and mutual hesitance during their informal communications, discussions can turn to business in a more relaxed manner. Officers talk about what kind of developments they are seeing in criminal strategies, share ideas about specific problems, and give each other information about what is going on in specific cases:

After an explosion took place, we found that the perpetrator had lived in a European Country before. We went to the liaison officer of this country and asked for information about this person and we got all the information. However we could not have gotten the same information through letters of rogatory from the judicial authorities of the same country. (Middle Eastern PLO, December 7, 2007)

Sharing information in this way helps all parties see beyond their own limited experiences and increases the chance of not only solving individual cases but also of identifying emerging trends.

Enabling this informality is an underlying sense of community among the PLOs and among the police in general (Marenin 2005) - a community characterized by common experiences, common problems, and common goals and recognized, at least rhetorically, by many police officers, regardless of nationality:

Let me give you an example. I was in the Paris airport, in the luggage area, and my wife took the first bags and passed through customs. I was waiting for the last bag, and eventually I realized that it wasn't coming and I was going to have to go somewhere else to report it. I needed to talk to my wife and tell her what was happening. I could see her through a glass wall but I couldn't get to her without passing through customs. I asked some airport employees and they all said it was forbidden for me to pass over and then come back through to deal with the missing bag. Then I saw a policeman. I showed him my own police badge and explained the situation to him. He immediately took me over, lifted a barrier and escorted me through to my wife, and then he brought me back through to deal with the bag. This is what being a policeman is all about. It's about looking at a situation, being practical and quick, and taking initiatives to solve the problem. He could do that for me because he knew I was a cop too, and he knew that I would do the same for him. This is our solidarity. (South Asian police director, December 4, 2007)

This sense of community seems to breed trust and enable informality, which arguably leads to practical solutions to the problems or crimes at hand:

When you're working on a case you can't wait for permission for everything. It's the same way as if I'm chasing a criminal on the street I have the right to take your car and chase him. My goal is to catch the criminal, and I'm not going to stand and wait for someone to tell me how to do it or if I can do it or not. (North American PLO, March 15, 2007)

The informal practices of the policing community also benefit from officers generally holding a common view of the problem: 
I don't see the issue as, like, "my" terrorists or "your" terrorists, I see them as terrorists, and I see them as bad. If you're a policeman and you want my help to catch a terrorist, I'm going to do whatever I can to help you. (North American PLO, March 12, 2007)

While one might question the degree to which this perceived apoliticized view of terrorism as a "crime like any other crime" holds true in all cases, it is undeniable that, to the extent to which it exists, such a "beyondthe-state" mentality of a police community can be particularly important for building up the cooperation necessary to counter transnational terrorism.

Equally if not even more important than PLOs' views on a sense of community or shared approaches to crime is the broad perception that PLOs seem to have of their evolving "liaisoning" practices. This evolving capacity of liaisons is revealed when PLOs speak of how past practices remain relevant for coping with new security problems:

When I started doing this work I remember how we spent most of our time chasing drug cartels and networks and now we're ordered to use most of our signalling and most of our capacity for the Jihadist networks. We sometimes use our old drug informants to find out what they know about fake passports or forged documents; things that might be used by terrorists. Back then our best friends in the foreign police headquarters were the cops from narcotics; now our best friends are cops from the counter-terrorism and intelligence departments. (European PLO, January 17, 2008)

The sense of evolving practices also comes through when PLOs talk specifically about current liaisonship efforts for countering terrorism:

Terror has a training characteristic. We were really compartmentalized in the past, but terror and political crimes has forced us to be familiar with all kinds of illegal international activity and now I think we're better prepared and ready for future changes. I think it has something to do with terror as a crime. I remember that as drug officers we used to say that no matter how much we did, some drugs had to be let through to meet the demand. Our job was just to stop excessive trafficking. There was a kind of limit psychologically against doing the job to the fullest. Countering terror needs to try and be $100 \%$ successful, so people try to go further and do better. This means that as liaisons we're really trying to keep our practices sharp. (North American PLO, March 21, 2007)

Still further evidence of changes in the nature of liaisonships and the role that they have come to play comes through in these words by a Turkish PLO:

The first time we went to Europe I was officially named as a "temporary position," that's how my position looked at in the budget department. Now my position and my colleagues is a permanent one. It's even in the law. No one asks now if my position will end and no one asks questions, they just know another liaison will come after me and another one. Even within the police ourselves, police cadets now realize that liaison posts are real and permanent, and they start to study languages to compete better for these posts. (March 11, 2008)

As noted earlier, the practice of posting PLOs to other countries or to international organizations is by no means a new one, but it is one that 
does seem to be changing in nature in response to a changing nature of threats. When transnational threats were only sporadic, PLO appointments were made in an ad hoc manner to meet the challenge. With the spread of international organized crime and drug trafficking, the frequency of PLO use rose, and various structures and practices were put into place, which are now being used in the fight against transnational terrorism. The "newness" of police liaisonships is not that they have just been discovered but rather that they are now becoming a recognized and institutionalized practice for responding to transnational threats of all kinds.

Overall, when we look at the patterns of PLO behaviors and convictions, we see that PLOs' activities are defining for them a position that cannot easily be categorized as precisely transnational or international. In their movement between the two ends of such a response spectrum, they-or more precisely, their practices of liaisonship-are instead samples of a form of transgovernmental activity in global security. The defining characteristics of their activity are their dynamism, flexibility, and adaptiveness combined with traditional elements like state capacity and legitimacy. Because theirs remains an expanding but as yet unclearly defined practice, it has the potential to disturb existing actors and patterns.

The most obvious sign of such a possibility is the tension still occasionally observed between diplomats (representing the international) and PLOs. ${ }^{5}$ In some cases, countries establish police liaisonships as an important part of their diplomatic relationships. The U.S. State Department, for example, is increasingly involved in international police matters because the international crime problem is officially viewed as a "component of foreign policy and national security, not just as a law enforcement issue" (Deflem 2001), and police cooperation programs are "part of the general foreign policy of the US" (Marenin 2001). For other countries, the relationship is neither as intertwined nor as clearly defined-a situation that may grant the PLO greater freedom but may also lead to tensions. One liaison officer from a European country described the relationship with his diplomatic mission as follows: "My Ambassador asked me quite a lot of times what I am doing as a liaison officer. And he still wonders why our country needs me" (interviewed December 15, 2007). A Middle Eastern liaison officer complained about his ambassador, saying that he "did not want to give me a room at the Embassy. He doesn't see my work necessary" (interviewed March 22, 2007).

These potential contradictions may reflect the hybrid nature of police liaisons-national representatives, working side-by-side with foreign police officers, and part of a global crime-fighting community. By contrast, the status of traditional representatives of the "international," such as diplomats, is very clearly defined. It is not surprising that the traditional actors of the international would be uncomfortable with the multilevel identities and capacities of the PLOs. This multilevel character of the PLOs seems to open up the potential for more relaxed and informal practices. 
PLOs have formal legitimacy but informal capacity. It is this bridging of the formal/informal gap in particular that may make them successful actors in the balancing of the international, state-centric realm and the transnational, multicentric one, and thus potentially effective responders ${ }^{6}$ to transnational terrorism.

\section{Building Blocks of Statist Transnationalism}

There seems little doubt among academicians and practitioners in general that the nature of security threats in the twenty-first century has undergone and continues to undergo changes. We are in an era in which states as unitary actors can no longer be considered either the primary sources of insecurity or necessarily the primary means of response to security threats. Instead, the world faces threats from a far broader range of actors, and along a much wider range of issues than interstate conflict. What remains a far more contentious issue is the question of the appropriate response to these new security threats: Who or what is best poised to counter them? Using what means? Are new actors and processes emerging to respond to these threats or are traditional actors adapting their means and stepping up to the plate?

Some answers or parts of answers to these questions are becoming clear. The appropriate and necessary response to transnational threats must also have transnational dimensions, and this demands cooperation on an international level and beyond-ultimately, a new kind of governance for transnational (in)security. In terms of agency to materialize this cooperation, the fact is that while most transnational security challenges originate and flourish in the constantly expanding transnational space, states remain in one way or another the primary responders. The resulting gap begs for an institutionalization of security-providing actors and processes for the transnational realm. The dynamics of the transnational space have thus far proven insufficient at producing such an effective and selfsustaining institutionalization from within. Private armies, institutes, or various other nonstate actors, who claim that they hold the potential to be part of such a response solution, remain for now premature in their physical capacity, and more importantly, have yet to establish credibility and legitimacy for such a global public service. In essence, we are left with the conclusion that the state-or some form of transgovernmental capacity - is the only realistic agent currently able to expand effectively into the transnational space and, by adapting and reorienting itself, counter rapidly expanding transnational security challenges, particularly violent ones.

There appear to be moves on the part of some substate actors to do precisely this. Unwittingly perhaps, one of the pioneer builders of transnational (in)security governance are the police, and on the front lines of this evolution are the PLOs. Police liaisons can be considered as a sign of a new kind of security governance, as they expand into new territories and 
assume and adapt new types of functions and practices, but do so with the strength that comes from statist legitimacy, prestige, and capacity. With their adaptations of standard procedures and pragmatic evolution of formal practices, they are merging the advantages of statist capacity with the adaptiveness of evolving transnational security practices. In doing so they are allowing us to identify emerging signs of what we can call "statist transnationalism."

Like transgovernmentalism, statist transnationalism describes the activities of substate elements acting in a transnational manner but differs with respect to the nature of these subunits' autonomy from the central state authority. In its original sense, transgovernmentalism presumes ineffective central control of the substate units. This lack of effective control allows the building up of informal transgovernmental working relations, which serve as the preconditions for an eventual "transgovernmental coalition building," in which the collaborating subunits from the different countries actually work together to influence international governance decisions. In contrast, cases like that of the PLOs show subunit contacts that are generally encouraged by the high-level officials as means for improving the effectiveness of international policies. Such activity can be perhaps more accurately described as statist transnationalism because the "state" remains emphasized. In this case, the relative autonomy from the state is at the level of practice, or what Keohane and Nye referred to as "transgovernmental policy coordination." In "true" transgovernmentalism, "autonomy" encompasses the identity of the actors themselves, and their presumed ultimate desire to strengthen their own positions vis-à-vis other subunits or the central authority itself. In statist transnationalism, autonomy is practiced on the basis of need, to effectively conduct the transnational nature of the mission.

At the same time, statist transnationalism seems to be a dynamic process, one that is in a sense building itself as it goes. As the PLOs cooperate more to solve cases, the transnationalist characteristics of the security governance also grow. Therefore, in principle, it is possible that the more the value of this practice is recognized as effective and therefore indispensable, the statist input (meaning statist legitimacy, operational capacity, and identity) will be less necessary. Does this mean that PLOs will move or are moving toward "true" transgovernmentalism as originally defined? The scope of this research does not yet suggest that these pioneering actors have either the intention or the true capacity to move beyond the crucial state input. This is due to the nature of the security threat they are fighting, a threat that requires an operational capacity that actors other than nation states are unable to accumulate and use. This includes everything from the most sophisticated high-tech equipment, to ready-to-die personnel, to the legal immunity that states can provide. Because of the high risks and demands involved in combating transnational terrorism, in this part of the security sector, there remains a need to label transgovernmental activity as statist transnationalism. In general, the 
adapted procedures and evolutionary practices that are labeled here as statist transnationalism can be said to evolve around three main characteristics: demonopolization of international security cooperation, informality, and depoliticization.

\section{Demonopolization of International Security Cooperation}

The first pattern to emerge when we look at the expansion of police liaison practices is the overall increase in unconventional-in this case, substateinstitutions or groups participating in the governance of transnational security issues. With their increased presence we see a demonopolization of international security cooperation, away from the days when such practices were dominated by national governments, foreign services, diplomats, and members of the intelligence community. Substate entities that were never a part of political international or transnational struggles are now taking more assertive and primary roles, such as can be seen in the example of local police departments engaging in cross-national security cooperation, through different forms of liaisonships as well as innovative practices like hiring nonprofessionals in advisory positions or as translators. The actions of these substate entities can be seen as signs of moving beyond traditional national constraints of viewing security issues as purely national level concerns, as detached from substate or nonstate involvement, or of being skeptical of other national interests-in the effort to address a common, transnational problem.

They may also be seen as having a long-term positive impact as their efforts provide impetus to traditional international agencies to reenergize and reorient themselves into the new transnational security environment. Basically, competition resulting from a demonopolization of security governance has the potential of bringing about more innovative and adaptive practices for transnational security cooperation. On the other hand, in the short term, a possible negative implication could be that competition between different groups could lead to coordination problems and could be advantageous for the targeted elements, for example, actors of global terrorism. Also in the short term, there is the obvious risk that demonopolization might not be smooth because high offices may dismiss these "junior" offices' capacity/practice at the international level-as reflected in the tension between diplomats and PLOs.

\section{Informality}

PLOs in the field attest to how face-to-face contacts and cooperation between people involved in security governance has increased since 9/11. They further note that these personal, informal contacts have been central to a growing reciprocity between substate entities such as national police organizations. If traditional national security contacts between countries can be considered as "dehumanized," these personal contacts are a way of 
"rehumanizing" security. In the world of the practitioner PLO, a national security issue like transnational terrorism, originally conceived as a part of politicized "high" politics, has merged with the realm of low politics by being seen as a criminal act. In this way, a formerly "high" politics issue has become a function of local, substate actors, alongside high-office statespeople and the military. Interestingly, these informal face-to-face contacts that are generally initiated in response to an immediate transnational security challenge also appear to be giving opportunities to the actors involved to discover other venues of cooperation. For example, the informal networks that were built up to combat drug trafficking have been adapted after $9 / 11$ for countering the global Jihadist challenge. These now strengthened informal networks can feasibly be utilized for future transnational security challenges. It is possible to anticipate, therefore, a spillover impact, in which cooperation on other transnational issues can also be realized, meaning that transnational (in)security governance has a dynamic potential to grow as the pathways of transnational security relationships are further consolidated.

The informality that these "cop-to-cop" practices employ appears to be used to go beyond the initial mistrust levels that traditionally poison the potential for global security cooperation. Still, one cannot ignore the sense that PLOs are probably more comfortable reporting such positive informal friendships than they would be reporting what they may actually experience in a foreign land, trying to work within a foreign institution. Surely there are many cultural—both ethnic and professional—differences that challenge the advantages of the informality argument. A critical example of this might be a foreign PLO's perception that some of the "local" or host police with whom he is working might have sympathetic feelings for the "enemy" (e.g., in Muslim states like Egypt or Pakistan). The foreign PLO might even question the potential of actual penetration by that enemy into the local forces. Even if unsubstantiated, such doubts would be devastating for the possibility for trust and informality that is so often mentioned and praised.

\section{Depoliticization of Security}

Finally, developments within police and PLO practice make clear how a depoliticization of security exchanges is important for an emerging transnational (in)security governance. Starting with the transnational threats themselves, the less politically defined the threat, and subsequently, the less politically formulated the countering frameworks and structures, the better the chances are for security cooperation and governance. When the focused-upon threat is viewed in a less contentious and political way-for example, as a crime to be controlled - the chances for mobilizing and overcoming obstacles to security cooperation are greater. Police officers' professional focus on terrorist threats as "crimes" rather than political acts improves their chances of being able to work with colleagues from 
around the world in spite of national, ideological, gender, or racial differences. To the extent they are able to achieve such a common, depoliticized perspective, the criminal then becomes for them the sole "other" and the common target. The police become a common "us," without allegiances to any particular state or affiliation, and are more likely able to maintain the trust and commitment necessary to cooperate fully and effectively.

Our interviews with acting PLOs lead one to believe that depoliticization is at work. It is not easy, however, to measure the degree of this depoliticization and, frankly, the genuineness of their comments and of their discourse of "us-the police versus them-the terrorists." Does this discourse continue when the PLO returns home and engages with his or her colleagues there? The professional interaction with other police is often reduced to highly focused, technical discussions about, for example, a particular terrorist cell's activities. They do not seem to discuss historical experiences with terrorism or enter into deeper discussions of the root causes of terrorism. One wonders whether the presumed "depoliticization" would carry through at that level and whether, therefore, the potential for "repoliticization" might be equally valid. It is one thing for a European and a Middle Eastern PLO to discuss the daily movements of an alleged local al Qaeda cell and quite another for them to talk about the role of the Palestinian conflict or the American action in Iraq with respect to that cell's motives.

\section{Conclusion}

The main question posed at the beginning of this article was whether states are proving capable of adapting their response practices to meet new, transnational security challenges, or whether a gap between the threats being now posed and states' capacity to respond to them is widening. The evidence here suggests that states, via their support and promotion of liaisonship practices in the critical realm of security, are showing their awareness of the need to adapt and are, in principle, adapting. This adaptability claim assumes a disaggregated understanding of the state, in which substate actors-still representing the state-are taking pioneering roles. Certain subunits of the state structure are proving better equipped to adapt to the needs of transnational activity and are doing so at the level of practice, for purposes of efficiency. As units of the overall state structure, these subunits' transnational practices represent change in the state. The fact that these subunits are going transnational without openly claiming their autonomy from the state speaks to the resilience of the state as a primary actor in international relations.

It is not a stretch to conclude that an apparent growth in a seemingly ad hoc practice of PLOs is evidence of states' capacity to adapt in response to transnational security threats. First, as shown above, PLOs are no longer an ad hoc phenomenon. Second, we must keep in mind that these moves are being made in the crucial sector of security. States are made most 
conservative, suspicious, uncooperative, and self-help driven by their instinct for survival -an instinct that is most obviously reflected in security issues. If, therefore, there is evidence that states are extending institutional capacities beyond traditional spaces, that they are promoting and consolidating nontraditional patterns in cooperative behaviors, it should be argued that this is a novel move and is a sign of transforming governance into the transnational on the part of those states-in other words, a reinventing of government.

Other areas of study (e.g., economics, law, health) have looked at the governance of transnational issues, observed a diversifying of governance, and concluded that the state as we know it is in decline. The increasingly independent activities of PLOs might appear as yet another example of such decline, but this is arguably incorrect because the intentions of the actor in question are still state oriented. The independence of these substate actors, described here as "transnationalization," is being done in order to have more efficiency to perform the job, not necessarily to build up stronger transnational loyalties - which may conflict with national ones. The situation is quite different from those substate (or nonstate) activities for issues like the environment, human rights, or health, which represent powerful, universally accepted norms and values, which may supercede actors' national loyalties. PLOs may be working together across borders, but their ultimate goals are aimed at protecting their state and its citizens. They remain pragmatic and are aware that without the state and all that it entails (its means, structures, institutions, legitimacy), their own transnational maneuvers and flexibility may not be enough to meet the transnational security challenge.

One can argue that states, through an internal "loosening" characterized by giving greater freedom and power to sub- and nonstate entities, are allowing a horizontal expansion of governance into the transnational space. However, as long as such internal loosening does not present destructive intragovernmental tensions, transnational achievements can be credited to states and their successful adaptation. By loosening, the state reveals and rediscovers its potential to become more efficient transnationally. Some scholarship only concentrating on the initial loosening may prematurely conclude that states are in decline, but the evidence in this article shows that it can also indicate a restructuring process for new formations. In this case, we see the evolving of transnational liasionships as signs of a better developed and consolidated form of public governance.

It has been suggested-although not shown - that transgovernmentalism is not an appropriate framework for looking at high politics (Raustiala 2002 , fn. 12). This attempt at exploring transgovernmental practices in a high-politics issue like national security suggests that this may be true, and therefore an alternative term of "statist transnationalism" is proposed. Statist transnationalism is in essence transgovernmentalism without the disconnection and defiance of state capacity that the latter presumes. Will statist transnationalism among security providers turn into transgovern- 
mentalism in the sense of a growing autonomy among the substate actors, an increasing lack of effective state control, and a growing effort on their part to influence governance decisions? There is at least some reason to suggest that for many countries, the answer is no.

Similar to the uneven impact that globalization and expanding transnational relations have on states, those states' responses to transnational forces are not all the same. "True" transgovernmental responses, in the sense of some degree of autonomy gaining by substate actors, are more likely to be seen in developed countries. In the developing world, response to security challenges still tends to be handled by centralized state forces, which are less likely to allow autonomy on the part of their substate actors. When we do see instances of real disaggregation of power in a developing or less developed state, it is more often the sign of a failing or failed state rather than transgovernmentalism. As these more centralized states must still find ways of responding to new transnational security challenges, "statist-transnational" solutions may seem a feasible option. Evidence that this may be the case can again be found in the words of the PLOs interviewed in this study, who were highly diverse in terms of their national backgrounds and the governance systems of those nations yet reported common practices and attitudes, which constituted statisttransnationalism rather than transgovernmentalism.

The possibilities for transgovernmentalism are also weakened for the same reasons mentioned above regarding the risk of repoliticization of practices if PLOs were to move beyond the technical discussions of on-theground activity. Repoliticization means in a sense renationalizing, and thus a probable maintaining of ties with national, central powers. Transgovernmentalism entails a weakening of these ties and an eventual desire to undermine or at least circumvent them. The potential of repoliticization is always close at hand in the case of sensitive security issues like transnational terrorism, and this potential lessens the likelihood of a materialization of true transgovernmental practices in the security realm. Practices of statist transnationalism in the governance of evolving security threats, however, as they are based on practical need, seem likely to continue and even grow in the foreseeable future. States and the transnational world converge for a practical need, which presents us with signs for long-term patterns in transnational governance.

\section{Notes}

1. For an overview of the nature of transnational threats see Smith (2002). For more focused studies on environmental issues as transnational threats see, for example, Barnett (2001), Dalby (2002), and McNeill (2005); on the spread of disease see Brower and Chalk (2003), Caballero-Anthony (2008), Kittelsen (2007), and Ostergard (2002); on migration see Collyer (2006), Faist (2006), and Lutterbeck (2006); on transnational crime see Swanstrom (2007); and on the rise of transnational terrorism see Enders and Sandler (2000), Sanderson (2004), Sandler and Enders (2005), and Wiktorowicz (2001). 
2. While disagreements remain over the ultimate significance of these forces, most would argue that their importance has grown relative to the Cold War era. For pioneering works on these transformations and forces see Rosenau (1990, 1997, 2003).

3. Although not specifically addressed under a heading of transgovernmental activities, some work being done on international police activities could be considered as indirect discussions of transgovernmental activities connected with security issues. For example, see Bigo (2000), Deflem $(2002,2006)$, and Sheptycki (2000, 2002).

4. The apparent predominance of American (and other developed world) liaisons might lead to concern over the possibility of an imbalance in PLO practices, with only limited countries being able to benefit from the exchange of information and valuable intelligence. In the case of transnational security issues, the concern may not be as relevant as with other issues. First, security is often prioritized in many poor countries, so money for PLOs is often found. Second, in the case of countering transnational threats, poor and rich countries alike have something to offer-it may often be that the poorer countries have valuable intelligence information. To gain access, the richer countries need the permission to place their own PLOs and might be willing, for that permission, to support the poorer countries, including those countries' PLOs. Such trade-offs have been common practice in international drug enforcement. While the money may therefore be found for poorer nations to send and support PLOs of their own, the real problem may actually be whether there are appropriate people to fill the PLO positions-for example, police officers with the language skills and international experience/personal adaptability to be able to establish good communication with Western counterparts on Western soil.

5. In fact, the more obvious place to look for such tension should be between the police and traditional security actors in counterterrorism, namely, members of national intelligence services. Unfortunately, it is extremely difficult to gather data on actors in or practices of the intelligence services, so one can only speculate how the interaction between them unfolds.

6. With respect to questions of effectiveness, again, it is impossible to measure precisely either the "effectiveness" of PLOs or the relative effectiveness of PLOs versus that of the presumably still more traditional practices of the intelligence services. Instead, we have to look for signs in other ways, for example, by considering that governmental decision makers are continuing to support liaison practices and are doing so in growing numbers. At minimum, therefore, it can be presumed that traditional approaches alone are no longer seen as adequate to combat transnational problems and that PLOs are considered as potentially useful supplements to those practices.

\section{References}

Adamson, Fiona B. 2005. "Globalisation, Transnational Political Mobilisation, and Networks of Violence." Cambridge Review of International Affairs 18 (1): 31-49.

Arquilla, John, David Ronfeldt, and Michele Zanini. 1999. "Networks, Netwar and Information Age Terrorism." In Countering the New Terrorism, ed. Ian O. Lesser, John Arquilla, Bruce Hoffman, David Ronfeldt, and Michele Zanini. Santa Monica, CA: RAND.

Avant, Deborah. 2005. The Market for Force: The Consequences of Privatizing Security. Cambridge: Cambridge University Press.

Aydinli, Ersel. 2008. "Before Jihadists There Were Anarchists: A Failed Case of Transnational Violence." Studies in Conflict and Terrorism 31: 903-923. 
Baldwin, David A. 1997. "The Concept of Security." Review of International Studies 25: 5-26.

Barnett, Jon. 2001. The Meaning of Environmental Security: Ecological Politics and Policy in the New Security Era. London: Zed Books.

Beck, Ulrich. 1999. World Risk Society. Cambridge, UK: Polity Press.

Behr, Hartmut. 2008. "Deterritorialisation and the Transformation of Statehood: The Paradox of Globalisation." Geopolitics 13 (2): 359-382.

Betsill, Michele M., and Harriet Bulkeley. 2004. "Transnational Networks and Global Environmental Governance: The Cities for Climate Protection Program." International Studies Quarterly 48 (2): 471-493.

Bevir, Mark, and R.A.W. Rhodes. 2003a. Interpreting British Governance. London: Routledge.

- 2003b. "Searching for Civil Society Changing Patterns of Governance in Britain." Public Administration 81: 41-62.

Bevir, Mark, R.A.W. Rhodes, and Patrick Weller. 2003. "Traditions of Governance: Interpreting the Changing Role of the Public Sector." Public Administration 81: $1-17$.

Bigo, Didier. 2000. "When Two Becomes One: Internal and External Securitizations in Europe." In International Relations Theory and the Politics of European Integration, ed. Morton Kelstrup and Michael C. Williams. London: Routledge.

Braithwaite, John. 2006. "Responsive Regulation and Developing Economies." World Development 34 (5): 884-898.

Braithwaite, John, and Peter Drahos. 2000. Global Business Regulation. Cambridge: Cambridge University Press.

Brower, Jennifer, and Peter Chalk. 2003. The Global Threat of New and Reemerging Infectious Diseases: Reconciling US National Security and Public Health Policy. Santa Monica, CA: RAND.

Burris, Scott, Peter Drahos, and Clifford Shearing. 2005. "Nodal Governance." Australian Journal of Legal Philosophy 30: 30-58.

Burris, Scott, Michael Kempa, and Clifford Shearing. 2008. "Changes in Governance: A Cross-Disciplinary Review of Current Scholarship." Akron Law Review 41: 1-66.

Buzan, Barry, Ole Waever, and Jaap deWilde. 1997. Security: A New Framework for Analysis. Boulder, CO: Lynne Rienner.

Caballero-Anthony, Mely. 2008. "Non-Traditional Security and Infectious Diseases in ASEAN: Going Beyond the Rhetoric of Securitization to Deeper Institutionalization." Pacific Review 21 (4): 507-525.

Cardenas, Sonia. 2003a. "Transgovernmental Activism: Canada's Role in Promoting National Human Rights Commissions." Human Rights Quarterly 24 (3): 775-790.

_ 2003b. "Emerging Global Actors: The United Nations and National Human Rights Institutions." Global Governance 9: 23-42.

Castells, Manuel. 2000. The Rise of the Network Society: The Information Age, Economy, Society and Culture. Hoboken, NJ: Wiley-Blackwell.

Chesterman, Simon, and Chia Lehnardt, eds. 2007. From Mercenaries to Market: The Rise and Regulation of Private Military Companies. Oxford: Oxford University Press.

Cohen, Jon. 2006. "The New World of Global Health." Science 311: 162-167.

Coll, Steve, and Susan B. Glasser. 2005. "Terrorists Turn to the Web as Base of Operations." Washington Post, August 7. <http:/ / www.washingtonpost.com/ wp-dyn/content/article/2005/08/05/AR2005080501138.html>. (November 20, 2010).

Collingwood, Vivien, and Louis Logister. 2005. "State of the Art: Addressing the INGO 'Legitimacy Deficit'." Political Studies Review 3 (1): 175-192. 
Collyer, Michael. 2006. "Migrants, Migration and the Security Paradigm: Constraints and Opportunities." Mediterranean Politics 11 (2): 255-270.

Crawford, Adam. 2006. "Networked Governance and the Post-Regulatory State? Steering, Rowing and Anchoring the Provision of Policing and Security." Theoretical Criminology 10: 449-479.

Csete, Joanne. 2004. Lessons Not Learned: Human Rights Abuses and HIV/AIDS in the Russian Federation. New York: Human Rights Watch.

Dalby, Simon. 2002. Environmental Security. Minneapolis: University of Minnesota Press.

Deflem, Mathieu. 2001. "International Police Cooperation in North America: A Review of Practices, Strategies, and Goals in the United States, Mexico and Canada." In International Police Cooperation: A World Perspective, ed. Daniel J. Koenig and Dilip K. Das. Lanham, MD: Lexington Books.

- 2002. Policing World Society: Historical Foundations of International Police Cooperation. New York: Oxford University Press.

- 2006. "Global Rule of Law or Global Rule of Law Enforcement? International Police Cooperation and Counterterrorism." Annals of the American Academy of Political and Social Science 603 (1): 240-251.

deNevers, Renee. 2009a. "(Self)Regulating War?: Voluntary Regulation and the Private Security Industry." Security Studies 18 (3): 479-516.

- 2009b. "Private Security Companies and the Laws of War." Security Dialogue 40 (2): 169-190.

Denning, Dorothy E. 2002. "Activism, Hacktivism, and Cyberterrorism: The Internet as a Tool for Influencing Foreign Policy." In Networks and Netwars: The Future of Terror, Crime, and Militancy, ed. John Arquilla and David Rondfeldt. Santa Monica, CA: Rand.

DesRues, Thierry. 2005. "Governability and Agricultural Policy in Morocco: Functionality and Limitations of the Reform Discourse." Mediterranean Politics 10 (1): 39-63.

Diawara, Mamadou. 2000. "Globalization, Development Politics and Local Knowledge." International Sociology 15 (2): 361-371.

Dorff, Robert H. 2005. "Failed States after 9/11: What Did We Know and What Have We Learned?" International Studies Perspectives 6 (1): 20-34.

Drahos, Peter, and John Braithwaite. 2003. Information Feudalism: Who Owns the Knowledge Economy? London: New Press.

Dupont, Alan. 2001. East Asia Imperilled: Transnational Challenges to Security. Cambridge: Cambridge University Press.

Eberlein, Burkard, and Abraham L. Newman. 2008. "Escaping the International Governance Dilemma? Incorporated Transgovernmental Networks in the European Union." Governance 21 (1): 25-52.

Edelbacher, Maximilian. 2001. "Austrian International Police Cooperation." In International Police Cooperation: A World Perspective, ed. Daniel J. Koenig and Dilip K. Das. Lanham, MD: Lexington Books.

Enders, Walter, and Todd Sandler. 2000. "Is Transnational Terrorism Becoming More Threatening?" Journal of Conflict Resolution 44 (3): 307-333.

Faist, Thomas. 2006. "Extension du Domaine de la Lutte: International Migration and Security, Before and After September 11, 2001." International Migration Review 36 (1): 7-14.

FBI Website. nd. <http://www.fbi.gov/aboutus/transformation/international. htm>. (November 27, 2007).

Ferguson, Yale, and Richard Mansbach. 2007. "Post-Internationalism and International Relations Theory." Millennium: Journal of International Studies 35: 529 549.

Fidler, David. 2004. "Constitutional Outlines of Public Health's 'New World Order'." Temple Law Review 77: 247-260. 
Freeh, Louis. 2002. Statement before the Joint Intelligence Committees, on the subject of Counter-Terrorism Efforts and the Events Surrounding the Terrorist Attacks of September 11, 2001. Federal News Service. Accessed via LexisNexis, December 18, 2006.

Freeman, Jody. 2000. "The Private Role in Public Governance." New York University Law Review 543: 818-858.

Fukuyama, Francis. 2004. Statebuilding: Governance and World Order in the 21st Century. Ithaca, NY: Cornell University Press.

Garland, David. 2000. "The Culture of High Crime Societies, Some Preconditions of Recent 'Law and Order' Policies." British Journal of Criminology 40: 347-375.

Gerspacher, Nadia, and Benoit Dupont. 2007. "The Nodal Structure of International Police Cooperation: An Exploration of Transnational Security Networks." Global Governance 13 (3): 347-364.

Hall, John A. 2002. "The Return of the State." Social Science Research Council. <http:/ /www.ssrc.org/sept11/essays/hall.htm>. (November 20, 2010).

Haque, M. Shamsul. 2004. "Governance Based on Partnership with NGOs: Implications for Development and Empowerment in Rural Bangladesh." International Review of Administrative Sciences 70: 271-290.

Hinde, Stephen. 2001. "Incalculable Potential for Damage by Cyber-Terrorism." Computers and Security 20: 568-572.

Holmqvist, Caroline. 2005. "Private Security Companies: The Case for Regulation." Stockholm International Peace Research Institute (SIPRI) Policy Paper No. 9.

Jonas, Andrew E. G., and Gavin Bridge. 2003. "Governing Nature: The Re-Regulation of Resources, Land-Use Planning, and Nature Conservation." Social Science Quarterly 84 (4): 958-962.

Jordana, Jacint, and David Levi-Faur. 2005. "The Diffusion of Regulatory Capitalism in Latin America: Sectoral and National Channels in the Making of a New Order." Annals of the AAPSS 598: 33-51.

Juergensmeyer, Mark. 2003. Terror in the Mind of God: The Global Rise of Religious Violence. 3rd ed. Berkeley: University of California Press.

Juska, Arunas. 2009. "Privatisation of State Security and Policing in Lithuania." Policing and Society 19 (3): 226-246.

Kempa, Michael, Philip Stenning, and Jennifer Wood. 2004. "Policing Communal Spaces: A Reconfiguration of the 'Mass Private Property' Hypothesis." British Journal of Criminology 44: 562-581.

Keohane, Robert O., and Joseph S. Nye. 1974. "Transgovernmental Relations and International Organizations." World Politics 27 (1): 39-62.

Kickbusch, Ilona. 2005. "Action on Global Health: Addressing Global Health Governance Challenges." Public Health 119: 969-973.

- 2006. "Mapping the Future of Public Health: Action on Global Health." Canadian Journal of Public Health 97: 6-8.

Kittelsen, Sonja. 2007. "Beyond Bounded Space, Europe, Security, and the Global Circulation of Infectious Disease." European Security 16 (2): 121-142.

Kittner, Christiana Brafman. 2007. "The Role of Safe Havens in Islamist Terrorism." Terrorism and Political Violence 19 (3): 307-332.

Krahmann, Elke. 2005. "Security Governance and Networks: New Theoretical Perspectives in Transatlantic Security." Cambridge Review of International Affairs 18 (1): 15-30.

. 2010. State, Citizens and the Privatisation of Security. Cambridge: Cambridge University Press.

Krasner, Stephen D. 1999. Sovereignty: Organized Hypocrisy. Princeton, NJ: Princeton University Press.

Krasner, Stephen D., and Carlos Pascual. 2005. "Addressing State Failure." Foreign Affairs 84 (4): 153-163. 
Lagon, Mark P. 2003. "Visions of Globalization: Pretexts for Prefabricated Prescriptions-and Some Antidotes." World Affairs 165 (3): 142-149.

Levi-Faur, David. 2005. "The Global Diffusion of Regulatory Capitalism." Annals of the American Academy for Political and Social Sciences 598: 12-32.

Loader, Ian, and Neil Walker. 2006. "Necessary Virtues: The Legitimate Place of the State in the Production of Security." In Democracy, Society, and the Governance of Security, ed. Jennifer Wood and Benoit Dupont. Cambridge: Cambridge University Press.

- 2007. Civilizing Security. Cambridge: Cambridge University Press.

Lutterbeck, Derek. 2006. "Policing Migration in the Mediterranean." Mediterranean Politics 11 (1): 59-82.

Mandel, Robert. 1999. Deadly Transfers and the Global Playground: Transnational Security Threats in a Disorderly World. Westport, CT: Praeger.

Marenin, Otwin. 2001. "United States International Policing Activities: An Overview." In International Police Cooperation: A World Perspective, ed. Daniel J. Koenig and Dilip K. Das. Lanham, MD: Lexington Books.

_ 2005. "Building a Global Police Studies Community." Police Quarterly 8 (1): 99-136.

Mathews, Jessica J. 1997. "Power Shift." Foreign Affairs 76 (1): 50-66.

McKenzie-McLean, Jo. 2006. Concern about Police Postings. New Zealand: The Christchurch Press Company.

McNeill, John R. 2005. "Diamond in the Rough: Is There a Genuine Environmental Threat to Security? A Review Essay." International Security 31 (1): 178-195.

McPhedran, Ian. 2004. "Federal Cops Stretched." Nationwide News Pty Limited, Png Post Courier, July 6, 3.

Messina, Anthony M. 2008. "Pathways from September 11: Politics, Policy, and State Sovereignty in an Age of Terror." PS: Political Science and Politics 41 (2): 419.

Metropolitan Police of London. nd. <http://www.met.police.uk/so/counter terrorism.htm>. (November 1, 2007).

Mlicki, Pawel P. 2001. "Police Cooperation with Central Europe: The Dutch Case." In International Police Cooperation: A World Perspective, ed. Daniel J. Koenig and Dilip K. Das. Lanham, MD: Lexington Books.

Mohler, Markus H.F. 2001. "Swiss Intercantonal and International Police Cooperation." In International Police Cooperation: A World Perspective, ed. Daniel J. Koenig and Dilip K. Das. Lanham, MD: Lexington Books.

Moran, Michael. 2002. "Review Article: Understanding the Regulatory State." British Journal of Political Science 32: 391-413.

Newman, Abraham L. 2008. "Building Transnational Civil Liberties: Transgovernmental Entrepreneurs and the European Data Privacy Directive." International Organization 62: 103-130.

Newman, Edward. 2007. "Weak States, State Failure and Terrorism." Terrorism and Political Violence 19 (4): 463-488.

O’Reilly, Conor, and Graham Ellison. 2006. "Eye Spy Private High: Reconceptualising High Policing Theory." British Journal of Criminology 46: 641-660.

Ohmae, Kenichi. 1995. The End of the Nation-State. New York: Free Press.

Ostergard, Robert L. Jr. 2002. "Politics in the Hot Zone: Aids and National Security in Africa." Third World Quarterly 23 (2): 333-350.

Paul, T. V., and John Hall, eds. 1999. International Order and the Future of World Politics. New York: Cambridge University Press.

Paul, T. V., John G. Ikenberry, and John Hall, eds. 2003. The Nation State in Question. Princeton, NJ: Princeton University Press.

Percy, Sarah. 2006. Regulating the Private Security Industry. London: International Institute for Strategic Studies.

Piazza, James A. 2008. "Incubators of Terror: Do Failed and Failing States Promote Transnational Terrorism?" International Studies Quarterly 52 (3): 469-488. 
Raab, Jorg, and H. Brinton Milward. 2003. "Dark Networks as Problems." Journal of Public Administration Research and Theory 13: 413-439.

Ramasamy, P. 2006. "Globalization and Trasnsnational Migration: The Malaysian State's Response to Voluntary and Forced Migration." Asian and Pacific Migration Journal 15 (1): 137-157.

Raustiala, Kal R. 2002. "The Architecture of International Cooperation: Transgovernmental Networks and the Future of International Law." Virginia Journal of International Law 43 (1): 1-92.

Rosenau, James N. 1990. Turbulence in World Politics. Princeton, NJ: Princeton University Press.

. 1997. Along the Domestic-Foreign Frontier: Exploring Governance in a Turbulent World. New York: Cambridge University Press.

- 2003. Distant Proximities: Dynamics beyond Globalization. Princeton, NJ: Princeton University Press.

Rotbert, Robert I. 2002. "Failed States in a World of Terror." Foreign Affairs 81 (4): 127-140.

Ruggie, John Gerard. 2003. “The United Nations and Globalization: Patterns in Limits of Institutional Adaptation." Global Governance 9: 301-321.

Sanderson, Thomas M. 2004. "Transnational Terror and Organized Crime: Blurring the Lines." SAIS Review 24 (1): 49-61.

Sandler, Todd, and Walter Enders. 2005. "September 11 and Its Aftermath." International Studies Review 7 (1): 165-170.

Sassen, Saskia. 1996. Losing Control? Sovereignty in an Age of Globalization. New York: Columbia University Press.

Schreier, Fred, and Marina Caparini. 2005. Privatising Security: Law, Practice and Governance of Private Military and Security Companies. Geneva: Geneva Center for the Democratic Control of the Armed Forces.

Scott, Colin. 2000. "Accountability in the Regulatory State." Journal of Law and Society 27: 38-60.

- 2002. "Private Regulation of the Public Sector: A Neglected Facet of Contemporary Governance." Journal of Law and Society 29: 56-76.

Sedgwick, Mark. 2004. "Al Qaeda and the Nature of Religious Terrorism." Terrorism and Political Violence 16 (4): 795-814.

Selin, Henrik, and Stacy D. VanDeveer. 2005. "Canadian-US Environmental Cooperation: Climate Change Networks and Regional Action." American Review of Canadian Studies 35 (Summer): 353-378.

Sell, Susan K. 2004. "The Quest for Global Governance in Intellectual Property and Public Health: Structural, Discursive and Institutional Dimensions." Temple Law Review 77: 363-400.

Shearing, Clifford. 2005. "Reflections on the Refusal to Acknowledge Private Governments." In Democracy, Society and the Governance of Security, ed. Jennifer Wood and Benoit Dupont. Cambridge: Cambridge University Press.

Sheptycki, James W.E. 2000. Issues in Transnational Policing. London: Routledge.

. 2002. In Search of Transnational Policing: Towards a Sociology of Global Policing. Surrey: Ashgate.

Sinden, Amy. 2007. "Harms Power and Responsibility: Why Human Rights Should Address Corporate Environmental Wrongs." In The New Corporate Accountability: Corporate Social Responsibility and the Law, ed. Doreen McBarnet, Aurora Voiculescu, and Tom Campbell. Cambridge: Cambridge University Press.

Singer, Peter W. 2001/02. "The Rise of the Privatized Military Industry and Its Ramifications." International Security 26 (3): 186-220.

- 2004a. The Private Military Industry and Iraq: What Have We Learned and Where to Next? Geneva: Geneva Center for the Democratic Control of the Armed Forces. 
2004b. "War, Profits, and the Vacuum of Law: Privatized Military Firms and International Law." Columbia Journal of Transnational Law 42: 521-550.

Slaughter, Anne-Marie. 2001. "The Accountability of Government Networks." Indiana Journal of Global Legal Studies 8: 347-368.

Smith, Paul J. 2002. "Transnational Security Threats and State Survival: A Role for the Military?" Parameters 30 (3): 77-92.

Spear, Joanna. 2006. "Market Forces: The Political Economy of Private Military Companies." FAFO Report No. 531.

Spiro, Peter J. 2007. "NGO'S in International Environmental Lawmaking: Theoretical Models." In The Oxford Handbook of International Environmental Law, ed. Daniel Bodansky, Jutta Brunnee, and Ellen Hey. Oxford: Oxford University Press.

Stiglitz, Joseph E. 2002. Globalization and Its Discontents. New York: Norton and Co. Stohl, Michael. 2006. "Cyber Terrorism: A Clear and Present Danger, the Sum of All Fears, Breaking Point or Patriot Games?" Crime Law and Social Change 46: 223-238.

Strange, Susan. 1996. The Retreat of the State: The Diffusion of Power in the World Economy. Cambridge: Cambridge University Press.

Swanstrom, Niklas. 2007. "The Narcotics Trade: A Threat to Security? National and Transnational Implications." Global Crime 8 (1): 1-25.

Takeyh, Ray, and Nikolas Gvosdev. 2002. "Do Terrorist Networks Need a Home?" Washington Quarterly 25 (3): 97-108.

Telhami, Shibley. 2006. The Return of the State in the Middle East. Washington, DC: Brookings Institute.

Teubner, Gunther. 2004. "Societal Constitutionalism: Alternatives to StateCentered Constitutional Theory?" In Transnational Governance and Constitutionalism, ed. Christian Joerges, Inger-Johanne Sand, and Gunter Teubner. Portland, OR: Hart Publishing.

Wakefield, Allison. 2003. Selling Security: The Private Policing of Public Space. Devon, UK: Willan Publishing.

Weiss, Linda. 1998. The Myth of the Powerless State. Ithaca, NY: Cornell University Press.

Wiktorowicz, Quintan. 2001. "The New Global Threat: Transnational Salafis and Jihad." Middle East Policy 8 (4): 18-38.

Xinhua News Agency. 2007. "Chinese Premier Attends ASEAN Plus Three Summit, Makes Five-Point Proposal." November 20.

Zedner, Lucia. 2003. "Too Much Security?" International Journal of the Sociology of Law 31: 155-184.

Zurn, Michael. 2004. "Global Governance and Legitimacy Problems." Government and Opposition 39: 260-287. 
Appendix

\begin{tabular}{|c|c|c|c|c|c|}
\hline & Country & $\begin{array}{l}\text { \# of } \\
\text { PLOs }\end{array}$ & & Country & $\begin{array}{l}\text { \# of } \\
\text { PLOs }\end{array}$ \\
\hline 1 & USA (DEA and FBI) & 122 & 29 & Czech Republic & 3 \\
\hline \multirow[t]{2}{*}{2} & \multirow{2}{*}{$\begin{array}{l}\text { France (Including } 56 \\
\text { SCTIP delegations) }\end{array}$} & \multirow[t]{2}{*}{72} & 30 & Estonia & 3 \\
\hline & & & 31 & Israel & 3 \\
\hline 3 & Germany & 49 & 32 & Japan & 3 \\
\hline 4 & Britain & 45 & 33 & Portugal & 3 \\
\hline 5 & Italy & 45 & 34 & Switzerland & 3 \\
\hline 6 & Spain & 36 & 35 & Colombia & 2 \\
\hline 7 & Australia & 28 & 36 & Croatia & 2 \\
\hline 8 & Netherlands & 25 & 37 & Lithuania & 2 \\
\hline 9 & Canada & 23 & 38 & Rep. of Korea & 2 \\
\hline 10 & Belgium & 17 & 39 & Albania & 1 \\
\hline 11 & Austria & 15 & 40 & Azerbaijan & 1 \\
\hline 12 & Sweden & 15 & 41 & Bolivia & 1 \\
\hline 13 & Belarus & 13 & 42 & Bosnia and & 1 \\
\hline 14 & Slovakia & 10 & & Herzegovina & \\
\hline 15 & Denmark & 9 & 43 & Chile & 1 \\
\hline 16 & Greece & 9 & 44 & Former Yug. Rep. of & 1 \\
\hline 17 & Ukraine & 9 & & Macedonia & \\
\hline 18 & New Zealand & 7 & 45 & Iran & 1 \\
\hline 19 & Poland & 7 & 46 & Luxembourg & 1 \\
\hline 20 & Turkey & 7 & 47 & Malaysia & 1 \\
\hline 21 & China & 6 & 48 & Mexico & 1 \\
\hline 22 & Norway & 6 & 49 & Pakistan & 1 \\
\hline 23 & Romania & 6 & 50 & Saudi Arabia & 1 \\
\hline 24 & Finland & 5 & 51 & Slovenia & 1 \\
\hline 25 & Hungary & 5 & 52 & Tunisia & 1 \\
\hline 26 & Ireland & 5 & 53 & United Arab Emirates & 1 \\
\hline 27 & Russian Federation & 5 & 54 & Venezuela & 1 \\
\hline \multirow[t]{2}{*}{28} & Bulgaria & 4 & \multirow{2}{*}{\multicolumn{2}{|c|}{ Total }} & \\
\hline & & & & & 647 \\
\hline
\end{tabular}

